University of Rhode Island

DigitalCommons@URI

Political Science Faculty Publications

Political Science

$1-27-2014$

\title{
The Costs and Benefits of American Policymaking Venues
}

Aaron J. Ley

University of Rhode Island, ajley@uri.edu

Follow this and additional works at: https://digitalcommons.uri.edu/psc_facpubs

Terms of Use

All rights reserved under copyright.

\section{Citation/Publisher Attribution}

Ley, A. J. (2014), American Policy-Making Venues. Law \& Soc'y Rev, 48: 91-126. doi:10.1111/lasr.12059

Available: https://doi.org/10.1111/lasr.12059

This Article is brought to you for free and open access by the Political Science at DigitalCommons@URI. It has been accepted for inclusion in Political Science Faculty Publications by an authorized administrator of DigitalCommons@URI.For more information, please contact digitalcommons-group@uri.edu. 
The Costs and Benefits of American Policymaking Venues

\author{
Aaron J. Ley, Ph.D. \\ University of North Dakota \\ Department of Political Science and Public Administration \\ Grand Forks, ND 58202-8379 \\ aaron.ley@business.und.edu \\ 701.777 .3549
}

Accepted: Law \& Society Review

09/09/2013

Acknowledgments: The author would like to thank Cornell W. Clayton, J. Mitchell Pickerill, Edward P. Weber, and the anonymous reviewers for their helpful advice in preparation of this article. 


\section{Institutional Choices in Legislatures, Courts, or Bureaucracies?}

Policymaking in a "separated" system occurs through multiple venues at the federal, state, and local levels (Kagan 2001; Jones 1994). An important debate surrounds the distinct costs and benefits of making policy in legislatures, bureaucracies, and courts. Scholars have long described the challenges of identifying these qualities in a systematic way. In his voluminous work on the concept of Adversarial Legalism, Robert Kagan (2001:4) admits "[t]here is no way to count up and compare all the social costs and social benefits that a gigantic, multifaceted legal system send rippling through economic, political, and communal life." In light of this challenge, maybe we can learn something about the relative costs and benefits of legislative, administrative, and judicial policymaking from those involved in policymaking processes. With the benefit of hindsight, what do stakeholders consider to be the costs and benefits of policymaking in all of these institutional venues available to them?

In this article, I use interviews with stakeholders who were engaged in an environmental conflict in the Pacific Northwest to describe what they perceived to be the costs and benefits of the multiple policymaking venues that were available to them. Through my interview data, I find that despite the various criticisms of judicial policymaking, stakeholders identified several important benefits in pursuing their policy goals through the courts that were lacking in other policymaking venues. It is possible that these findings have broad implications for those outside of the law and courts community, especially those who are interested in the debate over "venue choice." For those pressing for policy change, local conditions matter and the distribution of costs and benefits that are offered by these venues may shape the strategic choices they make. 
Finally, in a complex policy area where judges should be ill-suited to produce good policy outcomes, I show how litigation produced no worse an outcome than policy change achieved through a legislature and an agency on the same issue.

\section{The Costs and Benefits of Legislative, Administrative, and Judicial Policymaking.}

It is commonly thought that legislatures are where groups battle to define the terms of policy (Truman 1951), and representatives are held to account by the people (Dahl 1956). One benefit of legislative policymaking is that stakeholders exercise control over the process by bargaining with others (Dahl \& Lindblom 1953). Another benefit is that ordinary citizens, groups, or social movements may contribute to the passage of legislation without incurring major financial costs. Despite its advantages, the legislative process may also be problematic and frustrating. Legislatures are prone to gridlock (Binder 2003), may lack capacity to act on certain issues due to fragmented institutional authority (Whittington 2005), and are driven by reelection-minded representatives who choose sub-optimal short-term solutions over long-term costeffective ones (Mayhew 1974; Arnold 1992).

There is also a lot of debate about policymaking in agencies. Despite a large inventory of bureaucratic criticisms (see Goodsell 1983), there are several ways that administrative agencies can be optimal policymaking venues. Staffed by professional experts equipped with the knowledge to make reasoned decisions (Rourke 1984), agencies solve complex problems that are technical in nature. Furthermore, legislatures delegate policymaking authority to agencies that possess superior policy expertise or 
when putting together a legislative coalition and agreeing on the specific details of legislation becomes difficult (Huber \& Shipan 2002). Agencies can also be less attractive venues. Despite their ability to solve complex problems, some agencies come to rely on biased sources for information when making decisions (Ringquist 1993). Moreover, policy subsystems, or subgoverments, tend to develop under conditions of high administrative and legislative decentralization (McCool 1989); and certain professionals, such as economists, lawyers, or engineers, may come to dominate an agency (Mosher 1982).

While legislatures and agencies are both praised and criticized, arguably the most controversial forum for policymaking is the American judiciary. ${ }^{1}$ Critics usually raise at least one of three complaints. The first is that judicial policymaking is undemocratic, at least at the federal level where judges are not elected. Judges, therefore, lack democratic legitimacy and the accountability mechanisms possessed by legislatures and bureaucracies (Wechsler 1959; Bickel 1962; Ely 1980; Bork 1990). Furthermore, stakeholders lacking adequate representation in other branches of government turn to the courts (Rabkin 1989; Viscusi 2002), which grant rights that have not been acquired through traditional legislative processes (Melnick 1994).

The second major criticism is that judges are analytically challenged with respect to policy (Shapiro 1988; Rabkin 1989; Viscusi 2002; Derthick 2004). Judges are backward-looking in that they apply case facts to the law, while bureaucrats and legislative staff are capable of anticipating public problems (Viscusi 2002). This is particularly troublesome in complex policy environments where generalist judges are

\footnotetext{
${ }^{1}$ For more on this point, see work by Wechsler (1959), Bickel (1962), Horowitz (1977), Fuller (1978), Ely (1980), Melnick (1983, 1985, 1994), Shapiro (1988), Rabkin (1989), Rosenberg (1991), Kagan (2001), Viscusi (2002), and Derthick (2004).
} 
involved in determining what are appropriate, pragmatic, and effective responses to public problems (Kagan 2001). Gordon Silverstein (2009) shows how judicial decisions of this type can be path dependent, limiting policymakers' options for dealing with policy problems or entrenching what is sometimes bad policy.

Finally, some scholars argue that litigation in America is higher than usual (Olson 1991; Kagan 2001:126-155) and that there are strong incentives for individuals to pursue litigation over other means of conflict resolution (Burke 2002). Relatedly, others argue that Americans rely excessively on individual rights in political discourse and through legal processes (Glendon 1991). This discourages compromise and cooperation among those of different minds, and it may be a highly ineffectual way of getting things done (Rosenberg 1991).

On the other hand, these criticisms have been met by others claiming that courts are integral participants in the policymaking process for a number of important reasons (e.g., Barnes 2004; Busch, et al. 1999; Clayton 1994-1995; Pickerill 2004). Courts are key allies of national policymakers and reinforce, rather than blunt, majoritarian interests and values (Dahl 1957). ${ }^{2}$ Courts also preserve Constitutional commitments and bargains struck among competing interests who have toiled to achieve them (Landes \& Posner 1975; Ackerman 1991; Ginsburg 2003). Additionally, in very complex policy areas, courts are effective forums for activists and professionals seeking to reform longstanding bureaucratic pathologies (Epp 2009), redefine policy problems in new ways (Mather 1998), and by serving as a decentralized institutional apparatus that brings new policy problems into greater focus for national policymakers (Barnes 2009). Finally, there

\footnotetext{
${ }^{2}$ This point has been developed further Klarman (1996), Epp (1998), Pickerill and Clayton (2004), Frymer (2003), and Whittington (2005).
} 
remains no consensus in the scholarly literature about whether a litigation crisis exists in the American states. ${ }^{3}$

Whatever the case, courts can no longer be taken for granted in the policymaking process (Barnes 2004), and it is critical to assess their role at all levels of the government, whether it be state or national. Whittington (2005) provides a persuasive analysis of how courts function in the broader policy process at the national level by helping policymakers overcome legislative dysfunctions and obstructions, such as entrenched interests and fragmented coalitions. Furthermore, he finds that courts are critical for corralling "ideological outliers and members of the out-party [who] consolidate and exercise governmental power over limited geographic institutions" in state governments when federalism obstructs national policy goals (Whittington 2005:586). Do courts play similar roles in state policymaking processes?

Even if policymakers use courts to overcome obstructions in policymaking processes, it still leaves open the possibility that whatever was achieved by the courts was at the expense of good policy. In their analysis of the Oakland dredging saga over an extended period of time, Busch et al. (1999) show that courts are not always a barrier to good policy outcomes and that judicial intervention has a way of inducing negotiations that become widely accepted by a variety of stakeholders. In a similar vein, I systematically use a multiple case study design to assess the policy outcomes reached in an environmental conflict through legislative, administrative, and judicial means.

\footnotetext{
${ }^{3}$ Claims by tort-reformers of lawyers run amok are challenged by studies showing that tort tales rest on innuendo and faulty perceptions (Engel 1984; Daniels \& Martin 1995; Galanter 1998; Haltom \& McCann 2004; McCann \& Haltom 2006). Others find that filings and the length of trials have not increased substantially through the years (Kritzer 2004) and litigation naturally arises from broad social change and economic growth (Sarat \& Grossman 1975; McIntosh 1990; Jacobi 2009) or when there is institutional conflict between Congress and the President (Farhang 2010).
} 
The criticisms leveled on all three policymaking venues - legislatures, courts, and bureaucracies - remind us that all venues possess at least some traits that are undesirable. This study uses a multiple case study approach of an environmental conflict in Washington, Idaho, and Oregon to shed better light on how policymaking venues compare to one another and how stakeholders intimately involved in policymaking experienced these venues. These policymaking participants faced an identical environmental problem - the problem of agricultural field burning - that was resolved in different institutional arenas in all three states. It is, therefore, possible to assess whether stakeholders involved in this conflict described the costs and benefits of policymaking in these venues in ways that support or challenge the numerous perspectives scholars have put forth about institutional policymaking and how policy outcomes produced through judicial intervention compare with the outcomes produced by legislatures and agencies.

\section{Field Burning in Three Northwest States.}

Every year since the 1940s and during the late August months, farmers in Oregon, Washington, and Idaho burned crop residue from their grass fields because the practice produced more grass seed. The idea was that the burning shocked the plant into greater production and growers would only need to replant their fields every six to eight years instead of every three years, thus minimizing labor costs. Farmers also argued that the burning of bluegrass was beneficial to the environment by preventing the soil erosion that occurs from raking and removing crop residue.

Despite its virtues, efforts to keep the smoke from affecting vulnerable populations or tourists were made difficult by unpredictable wind patterns. The smoke produced from these burning fields impacted children with cystic fibrosis who were 
required to take long vacations with their parents during the burning season. When epidemiological research linking small particulate matter to respiratory disease began surfacing in the 1990s, medical communities in all three states joined forces with clean air activists to challenge the practice of field burning. Despite decades of political conflict over field burning, Washington, Idaho, and Oregon all came to resolve the issue in entirely different policymaking venues.

In 1998, the State of Washington became the first state to completely phase out the practice of field burning. Field burning was initially regulated by the Spokane County Air Pollution Control Authority (SCAPCA) until 1995. After Republicans assumed control of the Washington legislature in 1994, growers approached the legislature to strip SCAPCA of its authority to declare when and when not to burn. The legislation ignited a backlash and galvanized a citizens group called Save our Summers (SOS) who joined together with the American Lung Association (ALA) to ask the Washington Department of Ecology, the statewide agency with jurisdiction over air quality issues, to end field burning. With greater political support, and citing medical evidence linking fine particulate matter to poor health conditions, Washington's Department of Ecology banned field burning by 1998.

Oregon residents, on the other hand, persuaded the legislature to end field burning in 2009. In 1986, after limited visibility from field smoke caused a massive car pile-up on I-5 leaving dozens of motorists dead and injured, field burning made the public agenda and the legislature passed a bill limiting the number of acres burned. Despite several bills proposed by Eugene-area legislators to end the practice, lobbyists from the 
Oregon Seed Council, a grass seed industry trade association, successfully kept those bills from passing. It was not until 2009 - some twenty years after the deadly car pile-up - that an influx of Democratic legislators into the state assembly, with support from a coalition of public health and environmental groups, voted to phase-out field burning altogether.

Finally, agribusiness interests and farmers in Idaho exercised strong control over the legislature and the state administrative agency responsible for regulating the practice. Deterred by this blockage, a public health group called Safe Air For Everyone (SAFE) turned to the federal courts. SAFE unsuccessfully mounted its initial legal offensive using the Resource Conservation and Recovery Act (RCRA), a statute designed to regulate the disposal of solid waste. The Ninth Circuit's reading of the statute, however, did not recognize crop residue as fitting within the meaning of solid waste. Not long after unsuccessfully mounting its legal campaign, an attorney affiliated with SAFE noticed that field burning was not articulated as an allowable source of air pollution in Idaho's State Implementation Plan (SIP). ${ }^{4}$ When it was brought to the state's attention that field burning was omitted from the SIP, Idaho lawmakers immediately amended it to correct the mishap. This gave SAFE another opportunity to file suit with the Ninth Circuit, arguing that the EPA and Idaho were required to analyze the impact of field smoke before amending the SIP and adopting weaker regulations. The Ninth Circuit held that EPA's decision to approve Idaho's 2005 SIP amendment violated the Administrative Procedures Act, thus requiring the State of Idaho to undergo a comprehensive analysis of

\footnotetext{
${ }^{4}$ By now, readers may be wondering why this is an issue that was not dealt with federally. SIPs, in the tradition of partial preemption, allow states to experiment with designing their own air quality laws to reach the minimum federal air quality standards expressed in the Clean Air Act (see Crotty 1987). Being a subregional issue, and not one that was national in nature, field burning in the Pacific Northwest remained absent from the national environmental agenda.
} 
field burning's environmental impact. The end result was a negotiated regulatory agreement between stakeholders that placed regulatory authority over field burning in the hands of the Idaho Department of Environmental Quality and included more transparency about the location of burning activity.

\section{Methodology}

The time frame for this analysis begins in the 1960s, when field burning became a controversial topic in the states. Not only is the topic of field burning in the Pacific Northwest interesting because it was a conflict resolved in three different institutional venues, but it is also a conflict so technical and multidimensional in nature that we should expect that judges are the least capable actors for dealing with this issue and that positive perceptions of judicial decision-making by respondents should be unlikely. ${ }^{5}$

In this multiple case study design (see Yin 2009), I traveled across all three Pacific Northwest states - Washington, Idaho, and Oregon - to ask stakeholders what they perceived to be the various costs and benefits of influencing field burning policy in the many venues available to them. Using a snowball sampling method, I interviewed 35 farmers, industry officials, government employees, former and current legislators, journalists, academics, political activists, and attorneys who were all involved in field burning politics (see appendix for interview codes). After each semi-structured interview, which lasted anywhere from fifteen minutes to two hours, I asked respondents to identify additional stakeholders who participated in field burning politics.

\footnotetext{
${ }^{5}$ Legal Process scholars, such as Fuller (1978), argue that judges are best suited for resolving "dyadic" issues in comparison to "polycentric" issues. For an overview of this argument and a crucial case study showing that judicial power can be effectively employed to address polycentric policy problems, see Jeb Barnes's (2009) case study of Asbestos tort litigation.
} 
One challenge of sampling in this way is the availability of respondents. Some stakeholders were unavailable to speak about the controversy, some chose not to speak about it altogether, and, in some cases, there simply was not a lot of respondents to choose from. For instance, although I was able to speak with stakeholders on all sides of the Idaho conflict, the sample size is lower than the legislative and administrative conflicts of Oregon and Washington. Part of this is due to the fact that the policy conflict in Idaho involved fewer participants than in Washington and Oregon, where state legislators, regulators, and groups in moderately populated areas agitated for change. In those cases where a key stakeholder could not be reached for, or if he or she turned down, an interview request, I did my best to use archival materials and secondary sources to analyze the group or individual's position.

Notwithstanding these challenges, the strength of this sampling strategy is the identification of "hidden populations" (Spreen 1992) and the building of trust with respondents, which leads to additional referrals (Atkinson \& Flint 2001). In other words, I was able to sit down and speak with stakeholders who were not publicly identified as major players in the field burning controversy, thus increasing my sample size beyond those who were front and center during the controversy, which would have oversampled public relations professionals, Executive Directors, and so on. Furthermore, as I built rapport with these respondents, my access to elites - such as legislators, lobbyists, and policymakers - increased substantially and so did my sample size. Despite the challenges of identifying the entire population of participants involved in field burning politics across three states, nearly all of the individuals who were identified as potential 
respondents were eager to tell their story. I report and summarize the interview data in the next section, and follow with a discussion and my conclusions.

\section{Legislative Policymaking: The Costs of Lobbying and the Disadvantage of Entrenchment, Stalemate, and Socially Unconstructive Cooperation.}

Legislative Entrenchment. If legislatures are venues where stakeholders pluralistically battle to articulate societal goals, then this characteristic should be reflected in the personal interviews that I conducted with stakeholders in all three states. One of the characteristics making legislative policymaking problematic for clean air activists in Idaho was the entrenched nature of vested agricultural interests in the legislature. Although SAFE preferred a legislative approach (Personal Interview, PHA1), some stakeholders admitted facing tremendous barriers in having the Idaho Legislature resolve the issue. One legislator felt that voters sent her to the state legislature to end field burning, but when asked why it was not resolved, she responded that she was greatly outnumbered by the number of legislators who were farmers and legislated in ways that insulated the agricultural community from regulation (Personal Interview, SL1). One stakeholder in Oregon confirmed this point by saying, "What I was told about Idaho was their legislature protected field burning. So that's where they [the farmers] were showing up" (Personal Interview, PHA3). Another observer pointed out that, "The Idaho legislature has always been for the farmer, for the forester, and you other guys get out of here" (Personal Interview, AG7). 
Public health stakeholders in Oregon faced similar problems with legislative

entrenchment of agricultural interests. One individual described the ease with which the industry kept bills from being reported out of committee,

You have a very large industry that is very entrenched and powerful in the state and can pay for a whole lot of lobbyists who are very sophisticated at understanding the legislative process and are very good about the realities of trying to pass legislation. It is much harder than the realities of trying to kill legislation, it doesn't take a lot to create confusion, misinformation, laying out a scenario of economic woes and to dissuade enough people to go against this kind of legislation... (Personal Interview, SL4).

Even though stakeholders in Oregon predicted the passage of a field burning bill in 2007, the rules of the legislative game kept any bills from passing. One stakeholder described the frustrations of working through a fragmented legislature, a point that was confirmed in multiple interviews (Personal Interviews, SL3, SL4):

In 2007, we had to go to the ag committee because the decision had been made that it was going to be heard by public health AND by the ag [committee]. In 2009, by introducing a Senate bill it didn't have to go through the ag committee in the House because we already knew the ag committee was going to kill it. They have so much political clout and they're so aligned with the grass seed industry, so that was a huge thing...I'm not kidding you, [in] 2007 [a] grass seed grower got up there and testified to the public health committee and said, "Just get this to the ag committee. We'll take care of it there" (Personal Interview, PHA3).

One seed industry lobbyist laid out the seed industry's strategy during the 2007

Legislative session by explaining,

In 2007 it was the make-up of the House of Representatives, which was the critical blocking point, was 31-29. We had all 29 Republicans and we had at the time six or seven Democrats...We had nine total Democrats who said "No, we're not gonna do it [pass the bill to phase out field burning]." One of those was the Speaker and then several of the members of the Environment committee who didn't want to be seen supporting the legislation. [One legislator on the committee] went to the Speaker and said..., "We don't want that bill in our committee because it'll get out of control so you gotta send it, just for politics, to the health committee and then send it last to the ag committee and they'll bury it" (Personal Interview, AG7).

These responses illustrate the immense legislative obstacles that must be overcome when

traditionally dominant groups control it, obstacles that are further exacerbated by

geographical divisions within the states. 
Legislative Stalemate. Another disadvantage stakeholders faced in building legislative coalitions came from geographical factors. Southern Idaho legislators, who are traditionally a dominant political force and gatekeeper within the Idaho legislature, maintained very close ties to agricultural interests, leading to considerable policy stalemate over field burning. Southern legislators balked at the idea of regulating a farming practice even though that practice typically occurred in the north. Although as early as the 1990s some farmers in northern Idaho accepted the idea of regulation, southern Idaho legislators disagreed, worrying that it would invite future regulation of other agricultural practices. One northern Idaho farmer described the political strength of southern Idaho legislators and how their views of the controversy were shaped:

I don't think the south part of the state could even understand the argument that was going on in the north part of the state. I just don't think the agricultural community down there understood how controversial it had become. I've heard one farmer from Lewiston, Idaho say that if we stopped burning up here it would lessen the pressure statewide. (Personal Interview, FMR1).

Those from outside of the state also saw this playing out. When asked why Washington addressed field burning differently than Idaho, a Washington state official observed, "I think there was a concern that if they did something in Idaho to address North Idaho field burning that it would soon apply to Southern Idaho ag interests, which are pretty powerful" (Personal Interview, SR1).

Change agents in Oregon faced similar geographic obstacles. During the burning months, smoke hung in the Willamette Valley, out of sight from legislators in other parts of the state. Eugene-area legislators described the challenges they faced in persuading Portland legislators that field burning was an important state issue. One legislator put it in the following terms: 
In terms of population affected by field burning smoke, Eugene and Springfield, the metropolitan area of Lane County [where] you have upwards of a quarter of a million people, [where] smoke would hang for days and you would never get away from it. And you couldn't run for office without promising to do something about field burning. So it was in every campaign... [but the farmers] would corner the metropolitan Democrats from Portland who were always more willing to make a deal... [because] they didn't have to bear this stuff (Personal Interview, SL2).

Another legislator expressed the challenges of gaining political support from statewide

environmental organizations due to the regional impact of field burning:

They [the environmental groups] may have the public support in some areas of our state, but not statewide in order to win a battle like this. In fact, I was a little frustrated because I was hoping I would get a little more grassroots support from the environmental community than I did quite frankly... That was actually an interesting development and I kinda think that the environmental groups that were based in Portland looked at this as sort of a regional problem that they never saw. And they thought this would never happen. This has been fought for fifty years and nobody's been able to accomplish any other reductions (Personal Interview, SL4).

While stakeholders struggled to find support for ending field burning in Oregon, the geographical obstacle in Washington was even higher and little could be done to solve the conflict legislatively.

Washington State is politically divided by the Cascade Mountains that run north and south through the central part of the state and where the political power base is located in the western metropolitan area of Seattle and Tacoma. It was challenging for growers and regulators to convince western legislators that field burning required statewide action (Personal Interview, SR1, SR3, FMR4). When asked to elaborate on this obstacle, one state agency official said the following:

In general, I don't think that many of the legislators in Washington were attuned to the grass burning issue. It wasn't something that their constituents faced. For the grass growers a lot of it was centered in Spokane...I remember a lunch meeting in Olympia with the Director [of the Department of Ecology] and one of the Representatives from the Grant County area [who] tried to talk us out of making this decision of moving forward [to ban grass burning] but it was just time [to do it] (Personal Interview, SR1).

Despite the overwhelming consensus in Washington's medical community that burning

posed a threat to public health, it was nonetheless difficult to convince the legislature to 
act on an issue where the public health benefits of a burning ban were estimated to save \$8.4 million in public health costs (Holland, et al. 1997).

The Costs and Disparities of Lobbying Efforts. In all three states, stakeholders mentioned the financial burdens of legislative policymaking. Despite the grass seed industry's strength in the Idaho legislature, SAFE nevertheless worked through legislative channels in Idaho, costing the organization considerable financial resources. An attorney involved with the process observed that,

SAFE made a remarkable attempt [to settle the issue legislatively]. They went down and lobbied the legislature [and] flew doctors down. One legislative session ... we hired experts ... in epidemiology, toxicology, [and] doctors who had treated folks who were impacted. They really spent a lot of money trying to deal with it in a legislative fashion. They completely got shut out. And that was ... to see if they could work within the system before they sued (Personal Interview, ATY1).

In Oregon, where the legislative process played out over a number of decades, the costs of legislative policymaking were considerably higher.

Farm organizations in Oregon, for instance, made expenditures on behalf of growers to execute a public relations strategy. From 1981 to 2007, the Oregon Seed Council collected between $\$ 20,000$ to $\$ 200,000$ on any given year in membership dues from organizational members. Over that 27 year period, the Oregon Seed Council collected a total of nearly $\$ 3$ million from farmers and raised approximately $\$ 11.5$ million in total revenue to operate its organization. ${ }^{6}$ The organization spent an average of $\$ 25,000$ annually to convince legislators that regulation would cripple the industry and another $\$ 20,000-\$ 26,000$ annually on public relations and advertising to shape public opinion on the issue. One seed industry lobbyist described how this money was spent in a typical legislative session:

\footnotetext{
${ }^{6}$ Data were collected from Oregon Seed Council's IRS Form 990 from 1981-2007.
} 
The Seed Council, in addition to myself as a lobbyist, we hired another team to help lobby the issue so, when I say we, I mean the three of us were doing it. We started the session out by visiting [all] ninety Oregon legislators... Then we started with an educational packet for them, sat down for about a half-hour meeting with each and every one of them...We spent January and February doing that background educational work.

After that, there was a hearing held on a House Bill...so obviously we prepared testimony for that, the whole time encouraging farmers to come to the capitol... We had a few farmers make multiple trips and quite a few farmers make single trips to talk with their own legislators. We worked with them, preparing them for those meetings, [we] attended some, didn't attend others...[W] were working on that and it kinda got quiet for awhile until mid-late May when things started picking up and the bills started moving. And then we kinda prepared for meetings, all the while throughout that, during legislative meetings [we were] talking about the issue, vote counting, trying to line up votes...down to the $11^{\text {th }}$ hour to the last day when the bill finally passed the Senate and the House. (Personal Interview, AG6).

The Oregon Seed Council's approach to field burning in Oregon represents a systematic strategy to maintain a lobbying presence before the state legislature while the efforts of farm organizations in Idaho and Washington represented a similar strategy, albeit on a smaller scale (Personal Interview, FMR1). Based on their efforts to shape public opinion, build a body of evidence to support their positions, maintain their organizations, testify before committees, and conduct many other operations associated with working through legislative channels, it is likely that these lobbying efforts on behalf of agricultural interests were just as financially burdensome as other means of policymaking (e.g., litigation, regulation, etc.).

To be sure, public health advocates made expenditures to end the practice of field burning in Oregon and the other states, although finding accurate data for describing these expenditures is elusive. In my discussions with public health advocates, there was an overwhelming sense that one of the obstacles preventing active and systematic political participation was time and money, an issue not raised by agricultural interests when asked about the obstacles they faced in the legislative process. When one public health advocate was asked about the disadvantages they faced in legislative policymaking, he replied, 
Well, the biggest obstacle in that situation is always money and time. We weren't able to raise as much money to begin our campaign as we hoped...We just didn't have the resources for that so we went to Plan B and Plan C, which was figure out how to get free media as much as possible (Personal Interview ATY3).

Another stakeholder, a private citizen affiliated with public health interests, described

how the superior resources of the seed industry discouraged their effort to educate the

public of the negative consequences of burning. She described the disparity in resources

between the two sides by saying,

First off, they [the Oregon Seed Council] had a full-time lobbyist who had all the relationships. They were funded. They had these canned responses, you know, like, "Oh, it's [the smoke] not exceeding federal standards."...They were just much better organized and funded and also this is what broke my heart: their physicians in 2007, they had a physician get up there and say that this wasn't harmful (Personal Interview, PHA3).

Even those who were leading the effort to change policy through the legislature felt the odds were against them. An Oregon legislator said that the seed industry maintained strategic advantage by hiring one of the best lobbyists in the state. According to the legislator,

They hired the best lobbyist they could get. [He] was the grass seed grower's Seed Council secretary. He was their paid person. But they hired the best they could get for lobbying and poured money into it. Their argument, of course, was if field burning dies, we die (Personal Interview, SL2).

If it was not enough that the Oregon Seed Council hired a very successful and experienced lobbyist, the organization also enjoyed support from other organizations related to agriculture (Personal Interview, AG7). Even the legislators who were involved in passing a burning bill recognized the Seed Council's advantage of being part of a broader agricultural community of interests:

Historically, agriculture, like in most states in the west, is a very big piece of our economy and they're very well-funded. Its not a minor influence in the building. You have the Farm Bureau, the [Oregon] Seed Council is their own lobby as well and they would also join forces with the forestry. I mean, anything to do with agriculture would join together so you're dealing with very big lobby interests and very big industry interests who have a lot of resources compared to the environmental community (Personal Interview, SL4). 
One common thread tying public health advocates' and industry advocates' experiences with legislatures in both Idaho and, especially, Oregon is that it is costly, and those costs should not be taken for granted when assessing the costs presented by other policymaking venues such as bureaucracies and courts. While evidence has been presented demonstrating the costs of legislative policymaking, it may be that, despite these costs, legislatures are venues that encourage "social cooperation" among groups with divergent interests.

Legislative Contentiousness. Mary Ann Glendon (1993) argues that litigation impedes socially constructive cooperation (see also Kagan 2001; Rosenberg 1991), which implies that legislative institutions encourage it, but attempts to pass legislation in Oregon were marked by the same types of antagonism that is usually attributed to litigation. This is illustrated by one Democratic legislator's warning to seed industry interests after learning that the Oregon Seed Council was initiating a public relations campaign:

I know a little bit about market-testing and how to craft legislation. The day of reckoning is coming in Oregon. I won't put out a sucker bill as an initiative for them to pound on. I won't make a hobby of this industry. I will commit every day of my life to this issue, and I pledge you, I am not going to lose this fight (Duin 1989).

Committee hearings also became venues devoid of "social cooperation." State troopers were asked to escort a Eugene lawmaker through a group of farmers to one hearing and a Republican lawmaker threatened to stuff paper down the throat of a Democratic lawmaker (Dietz 2007). ${ }^{7}$

\footnotetext{
${ }^{7}$ In my conversations with stakeholders it was also evident that they held a negative view about the opposition. When referring to public health advocates, one Oregon seed industry referred to public health advocates as "the enemy." Another individual affiliated with public health interests characterized the seed industry as "self-serving." This tendency was common across all three states and in all institutions, suggesting that social cooperation may be elusive across many policymaking venues.
} 
If legislatures possess values that promote socially constructive cooperation, then efforts to find common ground should have been especially evident during or after the time that Oregon ended the stalemate over field burning in 2009. Industry officials and public health advocates, however, pointed fingers at one another for failing to compromise on the bill. According to one proponent of the legislation,

I couldn't even get a conversation with anybody to talk to me about it from the other side or to try to negotiate, "What can we do to solve this problem?" It was such a broad bill they felt, "Hell we don't want to talk. We're just gonna kill this bill because this is way over the top. He's trying to ban everything across the state." They didn't want to proceed with any kind of negotiations (Personal Interview, SL4).

On the agricultural side, opponents of the bill also described the opposition as unwilling to compromise. When one industry stakeholder was asked if there were efforts to compromise, he replied,

Yeah, there were. The proponents said all along the farmers were unwilling to compromise, that wasn't true. We were willing to sit down [and] talk all throughout the session. They wanted a complete ban. We wouldn't go to a complete ban so they said we weren't willing to compromise (Personal Interview, AG6).

Finding common ground in the legislature was elusive and, instead, the legislative process in Oregon produced an unfavorable outcome for Willamette Valley growers who stood on the losing end.

In conclusion, while Oregon lawmakers passed legislation banning field burning in the Willamette Valley, they did so while groups incurred considerable costs related to lobbying, public relations and advertising expenditures, and maintaining their organizations. These costs were also identified in the other states. Furthermore, those facing public health problems in all three states internalized the costs associated with breathing grass smoke because their legislatures were not designed to address regionally specific concerns or promote the cooperation necessary for resolving pitched policy conflicts. 


\section{The Benefits of Legislative Policymaking:}

\section{"Control" and Legislating in the Shadow of the Law (or Ballot Initiative}

Campaigns). Although it is evident that stakeholders were burdened by some features of the legislative process, it would be unfair to ignore the positive experiences that actors associated with legislative policymaking in Oregon. Some stakeholders described how they used the threat of litigation and a ballot initiative campaign so that the Oregon Legislature would act on the issue. Surely, litigation is expensive, but so, too, is a ballot initiative campaign and a lobbying strategy in the legislature. One member of the Oregon seed industry estimated the cost of a ballot campaign at about $\$ 1$ to $\$ 1.5$ million (Personal Interview, AG7). Others on the public health side admitted that a ballot campaign would cost them far too much to end field burning (Personal Interview, PHA3, PHA4, ATY2, ATY3, SL2). The conventional wisdom that litigation or ballot initiative campaigns may be costly is true, but threatening to litigate or launch a ballot initiative campaign comes at no cost to cash-strapped organizations.

Efforts to formally use costly litigation weighed heavily on the minds of all stakeholders in Oregon. One stakeholder on the public health side predicted that litigating would cost his organization between $\$ 250,000$ to $\$ 750,000$ and they were not willing to incur those costs without seeking a legislative solution first because, as he surprisingly put it, "As a lawyer, I look at myself as a problem-solver. What's the best way to solve a problem? From my perspective, the best way to solve the problem was legislatively" (Personal Interview, ATY3). Compared to Idaho groups, Oregon stakeholders had far more support from the environmental and public health community 
to pursue this strategy (Personal Interview, ATY3). He also admitted that litigation was

the last option for his organization:

\begin{abstract}
At the end of that legislative session, in June 2008, we knew that the legislative options would be the best - the most certain way to deal with the problem. So we looked at the administrative options for ending field burning and we wrote letters to the governor and pressured the governor to end field burning on his own, which he could have done. He chose not to do that so we essentially went through the Environmental Quality Commission, which is a governor-appointed commission with environmental issues because they had the power to end field burning but they punted so we looked at legal options. We worked with the City of Eugene and Lane County to use their powers of public nuisance to protect the people of their domains, jurisdictions as a means to bring a lawsuit against the industry for the problems that were created. Just the threat of that lawsuit changed the way the grass seed industry operated during that summer (Personal Interview, ATY3).
\end{abstract}

One legislator remembered having discussions about pursuing a legal strategy, but he considered it more appropriate to address the problem legislatively, saying that the benefits were, "More control over what happens and actually taking into consideration what I would consider to be some of the ramifications of having something "forced" upon people through the court system as compared to having something "forced" on them through the legislative system" (Personal Interview, SL3). With litigation posing a threat to the seed industry, the strategy paid dividends. Two stakeholders on the public health side recounted the strategy,

PHA4: They [the Western Environmental Law Center] talked about that [the litigation strategy] and they would never even tip their hands to us, but the threat was out there that we could haul them into court and I have no idea if that was feasible and obviously it would have cost money to do that.

PHA5: Well, also their strategy was for a complete ban, but they actually indicated they would have accepted something less than a complete ban, but they didn't want to tip their hand to anyone else because when negotiations are happening you don't want to lessen your position. I think they actually got a little bit more than what they really expected (Personal Interview, PHA4, PHA5).

Combined with other strategies, the credible threat of litigation or a ballot initiative campaign is a free tool that potentially saves organizations the expenditure of precious 
resources if it forces actors of different minds to reach a solution they would not otherwise have reached without the threat.

In conclusion, stakeholders' experiences with the legislature in all three states sheds light on the various costs and benefits of pursuing a legislative solution to field burning. Table 1 summarizes these various insights raised by stakeholders across all three states.

\section{Table 1 Here.}

\section{Administrative Decision-Making: The Costs of Capture, Program Costs, and Procedural Costs. \\ The Cost of Capture. The case of field burning policy in Idaho highlights the} special challenges public health groups faced in regulating grass smoke. It is reasonable to expect that policy matters dealing with air quality will normally involve environmental or air quality agencies with jurisdiction over these matters, but not in Idaho where jurisdiction was placed in the Idaho State Department of Agriculture (ISDA) rather than the Idaho Department of Environmental Quality (DEQ). Even if public health interests in Idaho were able to successfully pass legislation regulating grass smoke, they faced a high degree of uncertainty that a bill recognizing public health impacts would be faithfully implemented by the ISDA. Giving regulatory authority to the right agency was an important concern to the public health groups I interviewed. One member of SAFE wanted to shift regulatory authority from DEQ to ISDA because they felt ISDA was corrupt, incapable of regulating itself, and involved in secret backroom deals with farmers (Personal Interview, PHA1). Furthermore, they recognized that as a clientele 
agency the ISDA's job was to promote farming, while DEQ was independent enough and structurally designed to address pollution by virtue of its power to declare air emergencies (Personal Interview, PHA1).

What complicated efforts even further for public health groups was the structure of decision-making in Idaho government. One way that legislators sought to oversee agencies was by controlling the administrative rulemaking process through the legislative veto. If clean air groups successfully sought a rule through DEQ or ISDA, that rule would undergo legislative review, where at least one chamber of the Idaho Legislature is able to veto rules made by an executive agency. It was highly unlikely that a rule placing stricter controls on field burning would escape legislative scrutiny from lawmakers with such close ties to the agricultural community. One observer of the controversy considered it one of the fundamental differences that led to the legal outcome in Idaho and the administrative outcome in Washington:

The [Idaho] law was against the environmental agency instead of against the practice of field burning. In Idaho the legislature approves all of their administrative rules. In Washington the agencies do that and so there's a delegation of authority there that provides a political buffer so it's one step removed from legislative vote (Personal Interview, SR1).

The costs of administrative rulemaking in Idaho are clear. If public health advocates chose an administrative strategy, they would have incurred severe opportunity costs due to the legislature's control over the decisions made by Idaho agencies.

Program and Research Costs. Scholars frequently remark that the costs of litigation are one good reason for avoiding it and pursuing other means of dispute resolution. But while policymaking through litigation is costly, so was the cost of running policy programs and subsidizing research into alternative methods of crop disposal. Spokane's county-level air pollution control agency annually collected between 
$\$ 20,000$ to $\$ 45,000$ per year in burning fees that were used to cover the expenses of operating a program that regulated the time periods farmers could legally burn. The overall cost of the program over a ten year period was $\$ 268,610 .{ }^{8}$ Program costs in Washington paled in comparison to the costs incurred by Oregon's Department of Agriculture, which spent an average of $\$ 650,000$ annually to operate its smoke management program and $\$ 150,000$ per year to sponsor research on behalf of the agricultural community (Personal Correspondence, SR4). It is worth noting that, despite the generous funding that went toward discovering an alternative way of disposing of crop residue, decades of research produced nothing while those with respiratory ailments continued to internalize the public health cost of field burning.

Contentiousness in the Bureaucracy. The same contentiousness that bedevils participants in litigation and legislative processes also applies to the experiences of those making field burning policy in Washington. Farmers and members of a local clean air group clashed when volunteers traveled to farmers' fields to photograph and videotape the grass smoke:

[Two volunteers] went to film what happened and in the process went down a road that was unmarked... and began to photograph some illegal burning. Farmers saw them, surrounded their car, and tried to take away their video camera... When the Department of Ecology came to investigate, farmers surrounded and held those officials captive for...how many hours? Twelve hours? (Personal Interview, PHA1).

The above response represents an extreme example of contentiousness in Washington, but it was nevertheless common for the differing sides to be dismissive toward the views of one another. One farmer was asked about his view of the public health groups and he replied,

They were single-minded and they knew what they wanted and they went after it. They could care less about anything down here. They could care less about the natural

\footnotetext{
${ }^{8}$ Data were retrieved from the Spokane County Air Pollution Control Authority's annual reports.
} 
resources of the state. They could care less about agriculture...Even if it was only for a month or a week or whatever (Personal Interview, FMR4).

Even collaborative decision-making arrangements were not immune from the antagonism that inflicts legislatures, courts, and bureaucracies. Agencies and stakeholders participated in an initiative called the Inland Northwest Field Burning Summit, an effort to reach a negotiated agreement in a socially constructive way, but that also failed. An observer of the process recounted how "there was a lot of shouting back and forth because there were clean air advocates on the task force and scientists and farmers and there was a lot of rhetoric and positioning and concerns expressed" (Personal Interview, SR1).

Administrative Stalemate. James Q. Wilson (1989) identified how policies with diffused costs and concentrated benefits attract a small number of beneficiaries who lobby intensively for those policies. The fact that the costs of breathing grass smoke was so diffuse across the general population and that a small group of growers benefited from burning may be key in explaining what some respondents in Washington described as stalemate. In Washington, one regulator was disappointed in the lack of public input and described how he tried changing that at the time:

\begin{abstract}
So I decided to hold some public meetings in hopes of getting input from a number of interest groups on what they think would work in terms of a better alternative. ...I think I held at least two meetings and I was very disappointed in the amount of non-farmer input. The farmers showed up in force and pretty much in unison...There was almost no other public in the room so the public did not respond ...Several weeks later I held a second meeting in which I kinda put some concepts out there [for minimizing the impact of grass smoke]...Again, the room was full of farmers, almost no public, and this time they were just absolutely incensed. The message was, “... at our last meeting we told you what we wanted. Why are coming back with these other ideas when we told you what we wanted?" Again, there was no public input at all (Personal Interview, SR3).
\end{abstract}

The regulator's story not only demonstrates the public's apathy surrounding field burning, but it also demonstrates the adversarial relationship among farmers and regulators, even when the regulator sought farmers' input. It, furthermore, illustrates how 
producer groups face less arduous collective action obstacles than the general public.

The regulator went on to discuss how their relationship was never the same after holding this meeting:

\begin{abstract}
Meanwhile, behind my back, they went to the legislature and they told the legislative committee, "We have a real problem with our local air pollution control authority, they're not willing to work with us, they got us in this program that doesn't work, we need legislative relief." So what they asked the legislative committee for was basically no limits on the number of possible burn days (Personal Interview SR3).
\end{abstract}

The product of this meeting was a bill that was later passed by the legislature stripping SCAPCA of authority to manage field burning. The bill galvanized citizens concerned about public health to the point where they began seeking a ban through the State Department of Ecology (Personal Interview, SR3, AG5).

\title{
VIII. Administrative Policymaking: The Benefits of Technical Capacity and Incorporation of Local Knowledge from Professional Communities.
}

Washington was successful in its efforts to ban field burning, but it was several years before it acted on the issue. The implementation of Washington State's environmental statutes is entrusted to its state-level Department of Ecology, which is directed to identify economically viable alternatives to traditional economic practices before action is taken. The department's statutory authority allowed the agency to act quickly to end field burning after scientifically identifying the harmful impact of grass smoke and building political support from the region's medical community. Understanding the science that linked air pollution to public health costs was powerful evidence agency officials used to ban field burning, according to one official, who said:

One of the things that was a fascinating aspect to me of the federal Clean Air Act amendments in 1990 and then the Washington state Clean Air Act changes in 1991 was the focus on the comprehensive air quality policy,... and the announcement of changes on the hazardous substance side of air pollution control... There was a lot more information [at this time] coming forward about health impacts of fine particulate matter ... [which] emboldened the scientists and those who did risk assessments (Personal Interview, SR1). 
As the body of scientific evidence linking small particulate matter to public health impacts grew, it was only a matter of time before the public health community would use it as supportive evidence that field burning should be banned, thus demonstrating a traditional benefit of agency policymaking - the capacity to act in the context of technical complexity.

In addition to Washington's regulatory shift in approaching air pollution regulations, the Department of Ecology possessed the distinct advantage of having close ties to Spokane's local medical community. One agency official told the story of a doctor who played a key part in the agency's decision to pay closer attention to field burning:

[One doctor] sent a survey from his fax machine to everyone ... what do you think about grass burning? He asked if they had patients that were suffering from this, because he was sick and tired of seeing patients come in who are normally healthy and they just get hammered by the smoke inhalation in August and then they go into the fall season of colds and flus that their kids bring home. He was sick and tired of his patients being sick until spring of the following year. The survey came back and ...out of 600 that went out I think 597 came back and said that we have got to stop the practice of field burning... So that information came to Ecology's attention at the same time that we were learning more and more because that was part of our job in the air quality program to keep our eye on the national research of health effects in the particulate matter (Personal Interview, SR1).

The ability to take into account local circumstances is a major virtue for some administrative organizations and paved the way for Washington to make the determination that field burning negatively impacted public health and that it should be banned.

Administrative agencies also possess the capacity and financial resources to engage in large scale research prior to making formal choices. Prior to the ban, Washington state officials worked tirelessly in hopes of finding an economically viable alternative to grass burning. One agency official described the questions they sought to answer through research: 
Can you grow seed without burning? Question one. If yes, what are the consequences in regard to weeds and infestations and that sort of thing and then number three what do you do with the residue if you don't burn it? ...So we sent out a request for proposals and we got several and selected one that wasn't the growers' choice but showed some promise because it had been tested in Oregon and it had to do with research that was coming along with regards to how a grass seed plant makes seeds ... Normally the grass just makes lawn. When it is pruned aggressively it goes into the reproductive mode and makes seeds. And the farmers had been using fire to basically prune the grass to the point that it would bud like...your cherry tree. If you just let it be, you'll just get leaves. So we investigated (Personal Interview, SR1).

After reviewing the results of the research, the Department of Ecology chose to revisit its policy approach to field burning and began the process of certifying alternative ways of disposing of crop residue. This, in essence, ended the practice of burning Kentucky bluegrass residue altogether for growers.

In conclusion, just as there are costs and benefits to legislation and legal action, the same holds true for administrative policymaking. Table 2 summarizes the various costs and benefits of administrative policymaking in field burning politics, as they played out in Washington and Idaho.

Table 2 Here

\section{The Benefits of Judicial Decision-Making: Collaboration, Access, and Structured Development of Evidence.}

Some scholars of the policy process consider judges inimical to good public policymaking and the criticisms they level on the judiciary implicitly reflect some of the earlier charges made by Alexander Bickel (1962) and other critics (see e.g., Derthick 2004; Melnick 1994; Viscusi 2002; Kagan 2001). During the course of my interviews, however, stakeholders responded with insightful, and sometimes unique, observations about their experiences with judges and courts.

The Inclusiveness of the Judiciary. It is important to identify the reasoning that goes into making the strategic choice to choose the judiciary as a venue for the pursuit of 
policy goals. Stakeholders, for instance, may appeal to the judiciary in order to break through an entrenched and inaccessible policymaking arena. One stakeholder affiliated with SAFE described why legal action in the state of Idaho was necessary:

You have to remember that by the time SAFE was formed, this conflict had been raging in the region for over 20 years. Multiple efforts had been made to reach out to the industry, to hire a mediator early on...people were involved, active, and trying to bring some reasonableness to this issue and what became clear to citizens and activists over this twenty year period is that no matter what approach was taken with growers...industry got outraged. The industry... was going to fight until the bitter end (Personal Interview, PHA1).

Idaho stakeholders responded to this obstacle by using the RCRA's citizen suit provisions to seek their policy goals through the federal court system. During a hearing before the Federal District Court in Boise, SAFE's attorneys argued that the burning of crop residue was a hazardous waste when burned and was improperly disposed into the air. The judge in the case did not agree, but despite losing in Federal District Court, one stakeholder explained how failure in the judiciary is not always zero-sum in nature:

SAFE had spent a lot of money on the RCRA case, Judge Lodge ruled against SAFE and found that [farmers weren't] disposing solid waste and the Ninth Circuit affirmed. But the point is in that RCRA case we created a record - a very undisputed record - about how this practice harms people (Personal Interview, ATY1).

The effort was critical in the larger scheme of things because it gave the organization an accessible venue where they were able to accumulate a body of evidence that could be used in later cases and in other policymaking and institutional venues. The case of field burning litigation in Idaho, therefore, shows how interest groups can contribute to the policymaking process by accumulating a body of evidence that may be harder to produce in other institutions.

The inclusiveness of the judiciary also yields indirect benefits that are positive from a civic engagement standpoint. The volunteer citizens involved in the day-to-day operation of SAFE learned important skills about managing a nonprofit organization and 
understanding the legal process. This was all made possible by the hope provided by

possible legal remedies, and according to one stakeholder,

In order to join together for something, they sort of need a plan and some hope that things can change and, in fact, I think litigation offered the only avenue for change in this particular situation. It was clear that the state government was not going to be proactive and come up with some reasonable set of regulations for that industry. They didn't want to touch that with a ten foot pole (Personal Interview, PHA1).

Prior to the litigation in Federal District Court and in the Ninth Circuit, these stakeholders readily admitted to not possessing the same understanding of legal institutions that lawyers do, but that changed upon the resolution of the controversy. They worked with environmental lawyers as "legal researchers" and "clerks" in the months and days leading up to the litigation, learning how legal processes structure conflict in our most basic and solemn of American institutions.

Litigation Helps Build a Scientific Record. Several students of the legal process have been especially critical of the inability of judges to make decisions based on the best available scientific evidence (e.g., Viscusi 2002), but the litigation in Idaho led to the structured development of a scientific record in Idaho. In a white paper, SAFE explained how they went about building this record during the course of the RCRA case:

Expert witnesses were retained to demonstrate that grass residue met the legal definition of agricultural waste as defined by RCRA; that the smoke which was making people ill was in fact originating from grower's [sic] fields, and that the high particulate readings on air quality monitors were correlated with symptoms seen in the general public complaint records. Air modeling was done to demonstrate how the clouds of smoke travel in the region and impacted thousands of people...Agronomic experts demonstrated that Kentucky bluegrass could be grown for at least a four year rotation without burning and without drops in yields (SAFE 2002).

Even though they were not successful in this case and their subsequent RCRA appeal to the Ninth Circuit, they used the scientific evidence they had accumulated in that case to appeal a later EPA decision. One attorney described how the evidence developed from the RCRA suit "softened up" the Ninth Circuit for the later appeal: 
[If] you do the petition for review [of] an agency action the Ninth Circuit [has] original jurisdiction - they did get much of our record we created in RCRA. So the fact of the matter is, they could have [made the decision they did] because judges are people too...it was because this train had been moving forward and we had spent all that time and money creating evidence showing the harm that it was very easy for the Ninth Circuit to... just say, "clear procedural violation and, moreover, we're not even gonna hesitate [to end field burning] given what we know about this practice" (Personal Interview, ATY1)

By building this body of scientific evidence that was presented before the federal courts, SAFE was successful in sidestepping an entrenched bureaucracy and legislature that would not take the action necessary to meaningfully regulate the practice of agricultural field burning.

Litigation Enhances Public Input. Courts also possess virtues that enhance the public's input where other policymaking institutions seemingly fall short. To some observers of the controversy, agencies and legislators either did not have the time or the desire to give proper weight to the testimony given by asthmatics and respiratory sufferers, including the parents of victims. This was especially true in Oregon where one stakeholder explained the inefficacy of the legislative committee hearing process:

And even when I was testifying, I could tell the representatives that agreed with my position and the ones that didn't because nobody listened. Then we went to the ag committee [and one state legislator] had this great information about the impact of fine particulates and the chairman of the ag committee basically laughed. They said that flour was a fine particulate, should we be concerned about making pies? (Personal Interview, PHA3).

Another public health stakeholder in Oregon described how time was a limiting factor during the committee hearing process:

Two years ago we had this committee hearing and that was kind of a farce. They say, "Anybody can testify, you just come in." So you have one hour at the end of the legislature with a one year adjournment. So, okay, with twenty minutes to go, its open. So a couple patients get up and bang, time's up (Personal Interview, PHA5).

But while time for committee hearings may be a scarce commodity in Oregon's biennial legislature, one of the benefits of litigating is that stakeholders can make their 
experiences a matter of public record that will almost assuredly be read by a judge. One stakeholder, who was a mother of a child with respiratory ailments, described how this worked:

It was like the very first time that anyone had actually sat them [those with respiratory ailments] down and asked them what impact they suffered. No state administrative agency or person ever, ever asked these people what had happened to them. And, in fact, what I found even more outrageous was that the EPA held a series of hearings in the region....and I remember being just shaking with outrage because the EPA had set up this process by which farmers were privileged to tell us how tough it was for them economically if they could not burn. And yet, there was no forum for any victim of the smoke. And, I mean, I'm telling you there's a lot....[N]one of these people were invited or asked to talk about what burning did to them (Personal Interview, PHA1).

Although these individuals had access to the rulemaking and legislative process, no one asked for their depositions or gave anywhere near the amount of attention to their experiences than the judges did in the RCRA and Clean Air Act cases. One of the virtues of legal processes, therefore, may be confidence that proper consideration is given to the testimony of affected individuals.

\section{The Action-Forcing Nature of Litigation.}

While the threat of litigation led to legislation in Oregon, actual litigation led to a negotiated agreement between growers and public health advocates in Idaho. SAFE used its legal victory in the Ninth Circuit as leverage to force a compromise that was elusive in Idaho's legislature and regulatory agencies. The compromise came in the form of a negotiated regulatory agreement that emphasized transparency in the locations and number of fields burned and efforts to keep smoke impacts away from nursing homes and public schools. One stakeholder described how litigation forced this compromise in the following way:

So litigation did even the playing field and said, "Look, you have to take us seriously and we're going to be documenting publicly the outrage that people have had individually and collectively." I think I got something like 200 depositions of people who had been hurt by smoke, we collected all kinds of data, we showed that...decisions were being made that were inappropriate dangers for the public. In order to really use that lever for 
that change, I think litigation was really the way to go because it's a very systematic approach. When you're litigating you have to have a systematized approach to proving your point essentially in court...It was actually a wonderful process to go through I think because it really exposed the truth about what was going on (Personal Interview, PHA1).

In any event, growers still burn crop residue in Idaho, but it is done in such a way that SAFE can continue monitoring and alert respiratory sufferers when poor air quality is expected so that proper measures can be taken to prevent harm.

\section{The Costs of Litigation: Distrust, Delay, and Financial Costs.}

To be sure, groups in Idaho internalized a variety of costs when the field burning controversy was thrust into the federal judiciary. Many of these costs have already been identified in the literature on litigation, but it is still interesting to know how these costs were borne by stakeholders in this particular conflict. Farmers were especially frustrated with having to pay higher insurance premiums due to the possibility of litigation. One farmer described how the threat of litigation became a nuisance to growers in North Idaho:

It was the insurance companies, I don't know if you looked into the end of the insurance companies, but...it wasn't the state of Idaho that was gonna turn them off, it was the insurance companies that were gonna turn them off because they weren't going to provide insurance for them anymore...you have agriculture fighting agriculture at this point. And that was really interesting (Personal Interview, AG5).

Clean air advocates also incurred costs associated with litigation, but declined to disclose the donors covering their legal expenses because they were not legally bound by the same disclosure rules as lobbyists are in states like Oregon.

Farmers and activists in Idaho also experienced long periods of delay between attempts to litigate in one judicial venue over another. SAFE initiated its RCRA suit in 2002, but it was not fully resolved in the Ninth Circuit until 2005. It took another year to challenge EPA's approval of Idaho's SIP before the Ninth Circuit, and the final decision striking down the EPA decision was delayed until 2007. Even throughout this whole 
process, attorneys affiliated with SAFE did not trust the judge presiding over oral

arguments, who had developed a reputation for ruling in favor of extractive industries.

One attorney described the organization's experience with the judge:

...[the] Judge... is now a senior judge in Idaho, his family is a big agriculture family down in Southern Idaho. They actually come from the same community that I do. And they have big orchards. And they are ranchers. And historically his opinions have completely been for resource extraction and farmers/ranchers. We had a three way trial with [the] Judge on this issue and he summarily threw us out (Personal Interview, ATY1).

Overall, the costs associated with litigating in Idaho are as common as those described elsewhere by observers of legal processes (e.g., Kagan 2001). But the experience with litigation in Idaho, presents some insightful observations by the very individuals who were involved in the process. These various costs and benefits are summarized in Table 3.

\section{Table 3 Here}

\section{Discussion}

The different responses to field burning across all three Pacific Northwest states presents a unique opportunity to articulate what it is that stakeholders experience as the costs and benefits of institutional policymaking in legislatures, agencies, and courts.

Table 4 summarizes the various costs and benefits described by stakeholders and whether these costs and benefits were common across institutional venues.

Table 4 Here.

While the reader should keep in mind that the local institutional context differed in all three states, Table 4 shows that stakeholders describe their experiences across these venues in mixed ways. It is particularly interesting to note that stakeholders found the judiciary to be inclusive, while legislatures, usually known for their receptivity to popular 
demands, were not described in this way. Also surprising are the costs stakeholders associate with all three institutional venues, particularly financial costs and the opportunity costs associated with delay. It was apparent that, in this conflict, no matter which venue stakeholders chose for pursuing their policy goals, they would have been frustrated by delay while, at the same time, possibly incurring financial costs.

The results also suggest that litigation can be used to promote social cooperation indirectly. One common theme put forth by scholars is that those who lose in legislative processes turn to the courts as a negotiation tactic to extract concessions from political winners (e.g., Kagan 2001: 224-225). In the context of field burning politics, however, the outcome of the judicial strategy was arguably no worse than what was achieved in Oregon and Washington. In the area of environmental policy, Weber describes "'winwin' outcomes in the pollution control arena as those giving explicit consideration to [both] the environment and the economy" (1998:11). The outcome of the Idaho agreement was a win-win for both sides - farmers continued burning, but did so responsibly and under conditions that ensured the protection of public health. The legislative and administrative process in Oregon's Willamette Valley and Eastern Washington, respectively, ended the practice of field burning altogether. The legislative and administrative institutions conventionally associated with social cooperation and compromise failed to produce an outcome that left intact the ability of growers to burn. This technically-relevant solution in Idaho was made possible through litigation, which allowed public health advocates and farmers to negotiate a solution to what was a regional collective action problem. 
In addition to breaking down barriers that discourage cooperation, others have observed that litigation or judicial review is critical for reducing the inherent friction of legislative processes at the national level (Whittington 2005). Similar observations can be derived from the field burning controversy in the three Pacific Northwest states. Idaho stakeholders used the judiciary to overcome the legislative and administrative obstructions of stalemate, entrenchment, and gridlock. Furthermore, the Ninth Circuit was an institutional mechanism for overcoming the collective action problems associated with regional air quality issues. Smoke knows no man-made boundaries and one jurisdiction's choice to manage it is oftentimes foiled by another's decision not to effectively manage it. The Ninth Circuit intervention effectively placed Idaho on a path that would bring it into line with the emerging national consensus that small particulate matter is harmful and should be minimized.

Finally, these case studies offer insights to scholars interested in the topic of venue choice. Some scholars argue that groups strategically choose venues that "produce the most policy benefits for the cost incurred" (Sabatier \& Jenkins-Smith 1999, p. 142), while others argue that "policymakers and advocacy groups have pre-existing preferences for certain venues... [which means that] [f]ailure in one venue, or the existence of opportunity in another, does not necessarily mean that an advocacy group will shift venues" (Pralle 2003:242). If, in fact, it is true that groups strategically apply their resources in the venue that maximizes their policy benefits, then groups may be wise to strategically assess the institutional landscape to determine which characteristics of which venues give them the best chance of winning. On the other hand, if groups are culturally predisposed to certain venues, then it might be that they are attracted to the characteristic 
benefits that those venues offer. However, these two theories of venue choice need not be mutually exclusive. It might be that groups find a venue that gives them the best chance of winning and, win or lose, come to be culturally predisposed to a venue due to the types of resources they have built in that venue or their attraction to the benefits of that venue.

The problem of field burning in the Pacific Northwest provides a unique context from which to derive observations of the various costs and benefits associated with institutional policymaking, but the results of this study should be interpreted with caution. One obvious limitation of this study is that the costs and benefits of field burning across all three institutions may not be generalizable to other policy conflicts in other states. Another limitation is that the costs and benefits of policymaking across all three venues may differ depending on whose ox is being gored. For instance, those winning policy battles through the judiciary may speak positively of their experiences with courts, while political losers may overstate the costs of policymaking through these venues. Either way, this is an empirical question worthy of its own analysis and study. Finally, policymaking institutions are structurally different across states, and depending on that structure, costs and benefits associated with one type of legislature or agency may fundamentally differ from the types of legislatures or agencies in other states (or even agencies within the same state).

\section{Conclusion}

Robert Kagan (2001) is right when he argues that it is difficult to work out an overall balance sheet of the costs and benefits of the American legal system, but this study moves in that direction by identifying those tradeoffs through the eyes of 
stakeholders involved in an environmental conflict that takes place in different institutional venues across three states. I find that, contrary to the conventional wisdom, social cooperation is elusive across legislatures, agencies, and courts, although courts have a special role in encouraging cooperation in other venues. Moreover, the great financial costs of policymaking are not limited to the making of policy through the judiciary, but are also incurred in legislatures and agencies in the form of lobbying and executing agency programs. Finally, traditionally dominant groups find ways of entrenching their interests in these institutions and exploiting the fragmented geographical prerogatives of legislators. As others have observed, courts are a way of breaking through these traditional obstructions (Whittington 2005).

An equally important observation is that we should be careful about separating institutional policymaking into discrete units and painting any one institution with too broad of a brush. All three policymaking venues are very interdependent. Ninth Circuit judges did not deviate from what they were analytically capable of doing by undergoing rigorous cost-benefit analyses of ending field burning, but instead forced both public health groups and farmers in Idaho to reach a compromise after they had failed to do so for decades. The compromise also compelled the state legislature to act in a way that it had not for years and incorporated the concerns and views of public health groups in legislation that formalized the cooperative agreement reached by both groups. SAFE's victory was a jurisdictional and organizational one - a change in regulatory authority from Idaho's Department of Agriculture to the Department of Environmental Quality and greater public transparency to facilitate their "watch-dogging" role. Contrary to the outcomes produced by legislative and administrative venues elsewhere, burning in Idaho 
has been managed in a way that minimizes the impact of smoke on vulnerable communities. 


\section{References}

Ackerman, Bruce. 1991. We the People: Foundations. Cambridge, MA: Harvard University Press.

Arnold, R. Douglas. 1992. The Logic of Congressional Action. New Haven, CT: Yale University Press.

Atkinson, Rowland, \& John Flint. 2001. "Accessing Hidden and Hard-to-Reach Populations: Snowball Research Strategies,” 33 Social Research Update 1-4.

Barnes, Jeb. 2004. "Adversarial Legalism, the Rise of Judicial Policymaking, and the Separation of Powers Doctrine," In M. Miller, \& J. Barnes eds., Making Policy, Making Law: An Interbranch Perspective. Washington, D.C.: Georgetown University Press. . 2009. "In Defense of Asbestos Tort Litigation: Rethinking Legal Process Analysis in a World of Uncertainty, Second Bests, and Shared Policy-Making Responsibility," 34 Law \& Social Inquiry 5-29.

Bickel, Alexander M. 1962. The Least Dangerous Branch of Government: The Supreme Court at the Bar of Politics. Indianapolis: Bobbs-Merrill.

Binder, Sarah A. 2003. Stalemate: Causes and Consequences of Legislative Gridlock. Washington, D.C.: Brookings Institution Press.

Bork, Robert H. 1990. The Tempting of America: The Political Seduction of the Law. New York : Free Press.

Burke, Thomas F. 2002. Lawyers, Lawsuits, and Legal Rights: The Battle Over Litigation in American Society. Berkeley, CA: University of California Press.

Busch, Christopher B., David L. Kirp, \& Daniel F. Schoenholz. 1999. “Taming Adversarial Legalism: The Port of Oakland's Dredging Saga Revisited," 2 NYU J. of Law and Public Policy 179-216.

Clayton, Cornell W. 1994-95. "Separate Branches - Separate Politics: Judicial Enforcement of Congressional Intent,” 109 Political Science Quarterly 843-872.

Crotty, Patricia McGee. 1987. "The New Federalism Game: Primacy Implementation of Environmental Policy," 2 Publius 53-67.

Dahl, Robert A. 1956. A Preface to Democratic Theory. Chicago: University of Chicago Press. 1957. "Decision-Making in a Democracy: The Supreme Court as a National Policy-Maker," 6 J. of Public Law 279-95.

Dahl, Robert A., \& Charles E. Lindblom. 1953. Politics, Economics, and Welfare. New York: Harper and Row.

Daniels, Stephen, \& Joanne Martin. 1995. Civil Juries and the Politics of Reform. Chicago, IL: American Bar Foundation, Northwestern University Press.

Derthick, Martha A. 2004. Up in Smoke: From Legislation to Litigation in Tobacco Politics, $2^{\text {nd }}$ Edition. Washington D.C.: CQ Press.

Dietz, Diane. 2007. "Burn Ban, Rekindled," The Register-Guard, 8 April 2007, Sec. A.

Duin, Steve. 1989. "Kerans Meets Field Fires with Fire," The Oregonian, 16 April 1989, Sec. E. 
Ely, John Hart. 1980. Democracy and Distrust: A Theory of Judicial Review. Cambridge, MA: Harvard University Press.

Engel, David M. 1984. "The Oven Bird's Song: Insiders, Outsiders, and Personal Injuries in an American Community," 18 Law and Society Rev. 551.

Epp, Charles R. 1998. The Rights Revolution: Lawyers, Activists, and Supreme Courts in Comparative Perspective. Chicago: University of Chicago Press. 2009. Making Rights Real: Activists, Bureaucrats, and the Creation of the Legalistic State. Chicago: University of Chicago Press.

Farhang, Sean. 2010. The Litigation State: Public Regulation and Private Lawsuits in the U.S. Princeton, NJ: Princeton University Press.

Frymer, Paul. 2003. “Acting when Elected Officials won't: Federal Courts and Civil Rights Enforcement in U.S. Labor Relations, 1935-1985," 97 American Political Science Rev. 483.

Fuller, Lon. 1978. "The Forms and Limits of Adjudication," 92 Harvard Law Rev. 353409.

Galanter, Mark. 1998. "An Oil Strike in Hell: Contemporary Legends about the Justice System," Arizona Law Rev. 717-752.

Ginsburg, Tom. 2003. Judicial Review in New Democracies: Constitutional Courts in Asian Cases. Cambridge, MA: Cambridge University Press.

Glendon, Mary Ann. 1991. Rights Talk: The Impoverishment of Political Discourse. New York: Basic Books.

Goodsell, Charles T. 1983. The Case for Bureaucracy. Chatham, N.J.: Chatham House.

Haltom, William and Michael McCann. 2004. Distorting the Law: Politics, Media, and the Litigation Crisis. Chicago: University of Chicago Press.

Holland, David, Kathleen Painter, R. Douglas Scott, Philip Wandschneider, \& David Willis. 1997. "Estimates of the Benefits and Costs from Reductions in Grass Seed Field Burning." Olympia, WA: Washington Department of Ecology.

Horowitz, Donald L. 1977. The Courts and Social Policy. Washington, D.C.: Brookings Institution Press.

Huber, John D., \& Charles R. Shipan. 2002. Deliberate Discretion: The Institutional Foundations of Bureaucratic Autonomy. Cambridge, MA: Cambridge University Press.

Jacobi, Tonja. 2009. “The Role of Politics and Economics in Explaining Variation in Litigation Rates in the U.S. States," 38 J. of Empirical Legal Studies 205-233.

Jones, Charles O. 1994. The Presidency in a Separated System. Washington, D.C.: Brookings Institution Press.

Kagan, Robert A. 2001. Adversarial Legalism: The American Way of Law. Cambridge, MA: Harvard University Press.

Klarman, Michael J. 1996. "Rethinking the Civil Rights and Civil Liberties Revolutions," 82 Virginia Law Rev. 1-67.

Kritzer, Herbert M. 2004. "Review: American Adversarialism," 38 Law \& Society Rev. 349-383.

Landes, William M., \& Richard A. Posner. 1975. "The Independent Judiciary in an Interest-Group Perspective," 18 J. of Law, Economics, and Organization 875901. 
Mather, Lynn. 1998. "Theorizing about Trial Courts: Lawyers, Policymaking, and Tobacco Litigation," 23 Law \& Social Inquiry 897-940.

Mayhew, David R. 1974. Congress: The Electoral Connection. New Haven, CT: Yale University Press.

McCann, Michael, \& William Haltom. 2006. "On Analyzing Legal Culture: A Reply to Kagan," 31 Law \& Social Inquiry 739-755.

McCool, Daniel. 1989. "Subgovernments and the Impact of Policy Fragmentation and Accommodation," 8 Policy Studies Review. 264-287.

McIntosh, Wayne V. 1990. The Appeal of Civil Law: A Political-Economic Analysis of Litigation. Urbana, IL: University of Illinois Press.

Melnick, R. Shep. 1983. Regulation and the Courts: The Case of the Clean Air Act. Washington, D.C.: Brookings Institution Press. 1985. "The Politics of Partnership," 45 Public Administration Rev. 653-660. 1994. Between the Lines: Interpreting Welfare Rights. Washington, D.C.: Brookings Institution.

Mosher, Frederick C. 1982. Democracy and the Public Service, $2^{\text {nd }}$ Edition. New York: Oxford University Press.

Olson, Walter. 1991. The Litigation Explosion: What Happened when America Unleashed the Lawsuit. New York: Penguin Press.

Pickerill, J. Mitchell. 2004. Constitutional Deliberation in Congress: The Impact of Judicial Review in a Separated System. Durham, N.C.: Duke University Press.

Pickerill, J. Mitchell, \& Cornell W. Clayton. 2004. "The Rehnquist Court and the Political Dynamics of Federalism," 2 Perspectives on Politics 233-248.

Pralle, Sarah. 2003. "Venue Shopping, Political Strategy, and Policy Change," 23 J. of Public Policy 233-260.

Rabkin, Jeremy. 1989. Judicial Compulsions: How Public Law Distorts Public Policy. New York: Basic Books.

Ringquist, Evan. 1993. Environmental Protection at the State Level. Armonk, NY: M.E. Sharpe.

Rourke, Francis E. 1984. Bureaucracy, Politics, and Public Policy, Third Edition. New York: Harper Collins Publishers.

Rosenberg, Gerald N. 1991. The Hollow Hope: Can Courts Bring about Social Change? Chicago: University of Chicago Press.

Sabatier, Paul A., \& Hank Jenkins-Smith. 1999. "The Advocacy Coalition Framework: An Assessment," In P. Sabatier ed., Theories of the Policy Process. Boulder, CO: Westview Press.

SAFE. 2002. "Conflicting Missions: DEQ and ISDA - Smoke Management Efforts 2002," A White Paper.

Sarat, Austin, \& Joel B. Grossman. 1975. "Courts and Conflict Resolution: Problems in the Mobilization of Adjudication," 69 American Political Science Rev. 12001217.

Shapiro, Martin. 1988. Who Guards the Guardians? Judicial Control of Administration. Athens, GA: The University of Georgia Press.

Silverstein, Gordon. 2009. Law's Allure: How Law Shapes, Constrains, Saves, and Kills Politics. New York: Cambridge University Press. 
Spreen, Marinus. 1992. "Rare Populations, Hidden Populations, and Link-Tracing Designs: What and Why?" 36 Bulletin of Sociological Methodology. 34-58.

Truman, David B. 1951. The Governmental Process: Political Interests and Public Opinion. New York: Knopf.

Viscusi, W. Kip. 2002. "Overview." Regulation through Litigation, ed. W. Kip Viscusi. Washington, D.C.: AEI-Brookings Joint Center for Regulatory Studies.

Weber, Edward P. 1998. Pluralism by the Rules: Conflict and Cooperation in Environmental Regulation. Washington, D.C.: Georgetown University Press.

Wechsler, Herbert. 1959. "Toward Neutral Principles of Constitutional Law," 73 Harvard Law Rev. 1-35.

Whittington, Keith E. 2005. "'Interpose your Friendly Hand': Political Supports for the Exercise of Judicial Review by the United States Supreme Court," 99 American Political Science Rev. 583-96.

Wilson, James Q. 1989. Bureaucracy. New York: Basic Books.

Yin, Robert K. 2009. Case Study Research: Design and Methods, Fourth Edition. Thousand Oaks, CA: Sage Publications. 
Aaron J. Ley is an Assistant Professor of Political Science and Public Administration at the University of North Dakota. 
Table 1: Costs and Benefits Described by Stakeholders in Oregon and Idaho Legislatures

\begin{tabular}{llll}
\hline Costs & Mentions & Benefits & Mentions \\
\hline Entrenchment & $11(.61)$ & Control & $2(.11)$ \\
Stalemate & $9(.50)$ & Minimal Start-Up & $4(.22)$ \\
Financial & $7(.39)$ & $\begin{array}{l}\text { Leverage with } \\
\text { other Institutions }\end{array}$ & $4(.22)$ \\
Contentiousness & $6(.33)$ & & \\
Delay & $5(.28)$ & & \\
\hline Proportions reported in parentheses $(\mathrm{n}=18)$. & &
\end{tabular}


Table 2: Costs and Benefits Described by Stakeholders in Washington, Oregon, and Idaho Agencies ( $n=19)$

\begin{tabular}{llll}
\hline Costs & Mentions & Benefits & Mentions \\
\hline Capture & $5(.26)$ & Technical Capacity & $2(.11)$ \\
Stalemate & $4(.21)$ & $\begin{array}{l}\text { Linked to Prof. } \\
\text { Communities }\end{array}$ & $3(.16)$ \\
Contentiousness & $8(.42)$ & & \\
Delay & $4(.21)$ & & \\
\hline
\end{tabular}

Proportions reported in parentheses $(\mathrm{n}=19)$. 
Table 3: Costs and Benefits Described by Stakeholders in the Judiciary

\begin{tabular}{llll}
\hline Costs & Mentions & Benefits & Mentions \\
\hline Contentiousness & $2(.40)$ & Inclusiveness & $1(.20)$ \\
Financial & $4(.80)$ & Public Input & $2(.40)$ \\
& & Action-Forcing & $2(.40)$ \\
& & Body of Evidence & $2(.40)$ \\
& & Technical Capacity & $1(.20)$ \\
\hline
\end{tabular}

Proportions are reported in parentheses $(n=5)$. 
Table 4: Comparisons of the Costs and Benefits of Policymaking across the Three States

Legislature (ID, OR) Agency (WA, ID, OR) Court (ID)

Costs

Financial

Contentiousness

Delay

Stalemate

Entrenchment

Capture

\section{Benefits}

Enhanced Public Input

Technical Capacity/Scientific Record

Ties to Prof. Communities

Control

Minimal Start-Up

Leverage with other Institutions

Inclusiveness

Action-Forcing

Win-win Outcome 